\title{
Sexual violence against children and vulnerability
}

\author{
Luciana C. Trindade ${ }^{1}$, Silvana M. G. M. Linhares ${ }^{2}$, Jorge P. Vanrell ${ }^{3}$, Danilo Godor ${ }^{4}$, José C. A. Martins ${ }^{5}$, Stela M. A. N. Barbas $^{6}$ \\ Specialist, Nova Esperança Medical School (FAMENE), Department of Forensic Medicine of Parailba (DMI/PB), João Pessoa, PB, Brazil; PhD candidate in Bioethics at University of Porto, Portugal. \\ Specialist, Department of Forensic Medicine of Paraiba (DMI/PB), João Pessoa, PB, Brazil. \\ ${ }^{3}$ Specialist, Universidade Paulista (UniP), São Paulo, SP, Brazil. \\ ${ }^{4}$ Medical Student at Nova Esperança Medical School - FAMENE, João Pessoa, PB, Brazil. \\ ${ }^{5} \mathrm{PhD}$ in Nursing Sciences, University of Porto, Portugal. \\ ${ }^{6} \mathrm{PhD}$ in Civil Law, University of Porto, Portugal.
}

Work carried out by the Department of Forensic Medicine of Paraîba (DMl/ PB), João Pessoa, PB, Brazil.

Article received: $1 / 16 / 2013$ Accepted for publication: $7 / 1 / 2013$

Correspondence Rua Aderbal Maia Paiva, s/n, Q 245, L 198 Portal do Sol João Pessoa - PB ZIP Code: 58046-527 Phone: +55 83 3235-8831/ 3218-5214/ 9382-0781 trindadeluc@ig.com.br http://dx.doi.org/10.1590/1806-9282.60.01.015 Conflict of interest: none

\section{SUMmarY}

Objective: To analyze the demographic and epidemiological profile of children and adolescents victims of sexual violence treated in a Unit of Forensic Medicine and the relationship between victims and perpetrators.

Methods: A descriptive study, with data collection from information gathered from sex abuse reports performed in 2009 on victims of sexual violence aged less than 18 years. The data collection tool was a form filled out with demographic information about the victim - gender and age - and information regarding the sexual violence -, location of the occurrence, time elapsed between abuse and expert report, complaints reported, sexological examination findings, description of lesions outside the genital region, and aggressor's relationship to victim.

Results: In 2009, 421 individuals victim of sexual violence were assisted. Of those, 379 (90\%) were younger than 18 years, and 66 cases were excluded from these reports. Most were female (81.2\%). The most affected age group was 10 to 13 years old (36.7\%), followed by 5 to 9 year-olds (30.7\%). In most cases (86.3\%), there were family or friendship ties between victims and perpetrators, being most frequently accused an acquaintance or friend of the family (42.3\%), followed by the stepfather $(16.6 \%)$ and the father (10.9\%).

Conclusion: The results are similar to other studies conducted in the country. This work aims at filling a gap caused by the lack of research on this topic in the State, hoping to collaborate to improve public policies against child sexual abuse.

Uniterms: Sexual violence; child and adolescent protection; crime victims.

\section{INTRODUCTION}

Every child has the right to a healthy life, free of violence. Despite this, the World Health Organization estimates that millions of children around the world suffer from violence, directly or indirectly. Among its many forms, is sexual violence. ${ }^{1}$

Sexual violence is a universal phenomenon, affecting individuals of both sexes and all age groups. ${ }^{2}$ It seems to be embedded in a social, historical, and cultural context. ${ }^{3}$ In addition to the body and genital injuries that victims are subjected to at the time of abuse, there is an increased susceptibility to other types of violence in the future, as well as the possibility of contracting sexually transmitted diseases and developing psychological disorders. ${ }^{4}$ Therefore, it is seen as a complex public health problem., ${ }^{3,5-8}$
Sexual violence in Brazil is an old reality, being children and adolescents the most frequent victims. ${ }^{3,9}$ It is estimated that less than $10 \%$ of the cases of sexual violence against children and adolescents are reported. Still, the incidence and prevalence are considered high. Thus, in the 1980s and later, groups for child maltreatment prevention appeared in the country, culminating with the publication the Statute for Children and Adolescents., ${ }^{910}$

Erotic and sexual practices are imposed to children or adolescents through physical violence, threats or by inducing their will. They range from behavior where there is no physical contact (harassment, voyeurism, exhibitionism) to different types of acts with physical contact without penetration (oral sex, interfemoral intercourse, 
heavy petting, and frottage) or with penetration (fingers, objects, genital or anal intercourse). It also includes sexual exploitation, prostitution and pornography. ${ }^{11-13}$

In the country, sexual crimes are regulated by the 1940 Criminal Code (CC), modified by Law no. 12015, of 2009, which now classifies them as "crimes against personal dignity," currently being seen as an insult to freedom and sexual morality. ${ }^{14,15}$

The new law has a broader definition of rape, and included the rape of vulnerable, defined as "having unlawful carnal knowledge or practice other libidinous acts with a minor under 14 (fourteen) years," incurring the same penalty for those who practice these actions with someone who cannot offer resistance. ${ }^{15}$

The experience of sexual abuse can affect the development of children and adolescents in different ways, as some have minimal sequelae, or no apparent aftereffect, while others develop severe emotional, social and/or psychiatric problems. ${ }^{16-20}$ In addition, studies show that sexual violence is often accompanied by other forms of violence and violations of the rights of the child and adolescent. ${ }^{4,11,21}$ Other forms of parental or marital violence, such as physical abuse, psychological abuse and neglect, as well as community and institutional violence, are commonly present in the history of children and adolescent victims of sexual abuse. ${ }^{11,22}$

Given the above, it is clear that sexual violence needs to be consistently studied. This work focuses on the issue and has the goal of describing the demographic and epidemiological profile of children and adolescents victims of sexual violence seen at a Unit of Forensic Medicine in the Brazilian state of Paraíba, in 2009, as well as their relationship with the offenders and the injuries presented for forensic examination.

\section{Methods}

This study was conducted by the Department of Forensic Medicine of Paraíba (DFM/PB), an agency of the group that comprises the Institute of Scientific Police of Paraíba (IPC/PB), subordinated to the Secretariat of Public Security and Social Defense of Paraíba. The agency is located on the outskirts of the city of João Pessoa (PB), capital of a state located in the Brazilian Northeast region, and is responsible for performing expert medical examination of the victims (including in the case of sexual crimes) arising from the capital and surrounding cities.

The target population of this study consisted of reports of sexual violence of victims seen at the DFM/PB in 2009. The study included reports of victims of sexual violence, of both genders, who were less than 18 years old at the time the medical examination was performed, regardless of the time interval between the incident and the expert examination, and who were referred by a police or judicial authority.

Reports of victims older than 18 years, and females under 18 years, whose motivation for the performance of sexological exam was not considered as sexual violence, but otherwise related to their own desire, and/or the legal guardian's desire to know about or to prove the integrity of the hymen were excluded from the study.

It is a descriptive and retrospective documentary type study with a quantitative approach, for which data collection occurred in January and February 2011, based on information contained in the reports of sexological examinations done at the DFM/PB in 2009. The data collection tool consisted of a form filled out by the researchers, with sociodemographic information about the victims sex and age - and about the sexual violence - place of occurrence, time elapsed between the incident and the expert examination, the victim's complaints, findings of the sexological examination, description of lesions outside the genital area, type of offender and conclusion of the expert examination.

Data were entered, reviewed for typos, and analyzed using the Epi Info software program (3.5.3 version, CDC, Atlanta, USA). For data analyses, absolute and percentage frequencies were used.

The study was developed respecting all ethical principles regarding human research. The research project was approved by the Research Ethics Committee (CEP) of the Nova Esperança Medical School (FAMENE), with prior consent of the Director of the DFM/PB.

There was no conflict of interest in this research.

\section{Results}

In 2009, 421 individuals of both genders, victims of sexual violence, were attended to by the DFM/PB. Of these, 379 (90\%) were under 18 years old, whose reports of examinations constituted the study population; 64 cases were excluded (corresponding to $16.9 \%$ of the underage victims, and $15.2 \%$ of the total number of medical reports) on account of the motivation for the medical report, which was not defined as sexual crime, and 2 other victims ( $0.48 \%$ of the medical reports for underage victims, and $0.53 \%$ of the total number of reports) who refused to go through expert examination.

Of the 64 reports of under- 18 victims excluded, the motivations for the exam were: 4 (6.3\%) to confirm hymen integrity as desired by the victim or legal guardian; 
$31(48.4 \%)$ per request of the authorities, as part of the investigation of libelous accusation; 26 (40.6\%) due to the occurrence of consensual intercourse between a female over 14 years old and her boyfriend or partner (including 3 for "marriage purposes"), and 3 (4.7\%) for genital trauma.

As for the sociodemographic characteristics of the victims of sexual violence in this study, 254 were female (81.2\%, confidence interval $76.4-85.3 \%)$. A minority, 59 of them (18.8\%, confidence interval $14.8-23.7 \%$ ), were male. With regard to age, victims were divided into four groups. The median age was 10 years. The most affected age group was 10 to 13 years old (36.7\%), followed by 5 to 9 year-olds $(30.7 \%)$ (Table 1$)$. Considering age alone, most of the victims were 13 years old (14.1\%).

The municipalities with the highest number of complaints were João Pessoa (55.3\%), Santa Rita (10.5\%) and Bayeux (4.2\%), the latter two located in the metropolitan area of the capital of the state of Paraíba.

\section{TABLE 1 Age range of victims}

\begin{tabular}{l|l|l}
\hline $\begin{array}{l}\text { Age range } \\
\text { (in years) }\end{array}$ & Frequency & Percentage \\
\hline 0 to 4 & 52 & $16.7 \%$ \\
\hline 5 to 9 & 96 & $30.6 \%$ \\
\hline 10 to 13 & 115 & $36.7 \%$ \\
\hline 14 to 17 & 50 & $16.0 \%$ \\
\hline Total & 313 & $100 \%$ \\
\hline
\end{tabular}

The time elapsed between the incident of sexual violence and the medical examination was less than 24 hours in $8.6 \%$ of the cases, one day in $9.6 \%$, two days in $3.5 \%$ of the cases, three days in $5.8 \%, 4$ to 29 days in $11.7 \%, 30$ to 60 days in $5.1 \%$, over 60 days to a year in $10.9 \%$ of the cases, and 5 years in $0.6 \%$ of the cases. This time interval was not described in $44.2 \%$ of reports.

In most cases (86.3\%), there was a link between victims and defendants, and most often the defendant was a family acquaintance or friend (42.3\%), followed by the stepfather (16.6\%) and father (10.9\%). Other relationships observed less frequently were: cousin (2.6\%); uncle (2.6\%); grandmother's or aunt's partner (2.2\%); brother, godfather and neighbor, each of them with a frequency of $1 \%$; superior, sister's father in law, and mother's ex-husband, each with a frequency of $0.3 \%$. In 20 cases (6.4\%) there was no information in this regard.

As for body injuries presented by victims outside the genital region, $49.5 \%$ did not have any evidence, in $47.3 \%$ of the reports there was no reference to such information, and $10 \%$ of victims had lesions.

The most common types of sexual violence suffered by the victims, according to the conclusion of the expert reports were: the absence of traces of violence (64.2\%), rape of vulnerable person (13.7\%) and inconclusive results $(9.9 \%)$. Other findings were: libidinous acts (7\%), anal rape (3.2\%), vaginal rape (1.6\%) and other (0.3\%).

\section{Discussion}

Sexual violence is defined as any sexual act or play, heterosexual or homosexual relationship, in which the aggressor is in a more advanced psychosexual development stage than the child or adolescent, with the purpose of sexually stimulating the victim or using him/her for sexual stimulation. ${ }^{9.12,13}$

It constitutes a complex problem, with cultural roots, that reaches the field of morality and the protection of human rights. Sexual violence has many severe consequences, compromising the development of children and adolescents, possibly inserting the victims in a cycle of violence that can continue into adulthood. ${ }^{3-5}$

In Brazil, victims under 14 years are legally considered vulnerable. Vulnerability from the perspective of bioethics is defined as a relationship of inequality between two individuals or among groups, in which one party has its will annulled or diminished. ${ }^{23.24}$ Primarily related to the field of research only, the term began to be used also in everyday situations, such as gender inequality, social exclusion of groups, in relation to the elderly, and more. ${ }^{13,24-26}$

The phenomenon of violence has also become of interest in bioethics, not only because it involves the breaking of the victims' autonomy and human rights violation, but also because these victims have often already suffered social vulnerability. ${ }^{4}$ Moreover, from the perspective of distributive justice, there is an interaction with public health: sexual violence being seen as a public health problem, the interest in the topic by both fields of knowledge is justified. ${ }^{26.27}$

In the present study, the majority of victims of sexual violence were children and adolescent females, which is consistent with results from several Brazilian investigations. ${ }^{2,9,28}$ For Ribeiro et al, this can be related to the domination and exploitation of the female gender. ${ }^{3.4}$

Regarding age, in this study, the majority of the victims were between 12 and 14 years, followed by children 9-11 years old, similar to the findings of Ribeiro et al. ${ }^{3}$ These results differ from studies of other authors, who have found that the most affected age range was that of 5 to 10 year-old children. ${ }^{3.8,12}$ 
In terms of the location where the incidents occurred, some authors found that, in most cases, they occur in the victim's home. For these authors, the home environment makes abuse easier because it keeps the victims away from prying eyes ${ }^{3}$ De Lonrenzi et al found the father as the main responsible for the sexual aggressions. ${ }^{28}$ Uncles and brothers were also cited as responsible, after the stepfather and father, by Ribeiro et al. ${ }^{3}$ Habigzang et al, analyzing legal cases that occurred between 1992 and 1998 in Rio Grande do Sul, found that those responsible for sexual abuse were usually relatives or people who had a relationship of trust with the victim's family. ${ }^{11}$ The present study also found that individuals accused of these crimes had, in most cases, some degree of relationship with the victims, being the father and stepfather link the most frequent. This suggests that criminals use the protection provided by private setting, the possible trust of the victims and their families, and his/her power over them ${ }^{29}$, which characterizes, in the opinion of the researchers, qualified vulnerability.

Considering the time elapsed between sexual crime and medical expertise, intervals over 72 hours were frequently observed, which allows evidence to be lost, making the forensic examination more difficult. ${ }^{30}$ This may reflect what some studies present about allegations of sexual abuse involving children and adolescents: in most cases, the complaints are not made due to feelings of guilt, fear of threats, shame and the victim's tolerance. In addition, other factors contribute to this situation, such as the reluctance of some doctors to recognize and report abuse, the insistence of courts on strict rules of evidence, and fear of family breakdown when the incident is revealed. ${ }^{31}$

In sexual offenses, the use of physical force can determine genital lesions evidenced by forensic medical examination. ${ }^{7}$ The expert examination allows the victim to be assessed through analysis of body, clothes or biological samples such as blood or sperm. However, in many cases, as occurred in $65 \%$ of reports of this research, no evidence is found, which does not deny the sexual abuse, but makes it more difficult for the authorities to manage the case. ${ }^{29}$

Still analyzing the forensic examinations, the researchers found inconclusive results in approximately $10 \%$ of the reports, and lack of violence in approximately $65 \%$ of them. These results may be a consequence of the long length of time between the violence suffered by the victim and the medical examination, or the fact that the crime does not leave evidences, such as the various forms of libidinous acts (fondling, introduction of fingers without damaging natural orifices, oral sex, genital manipulation, among others), and the situation of former rape (over 72 hours) in female victims with previously ruptured hymen, or even complacent hymen.

In addition to the genital lesions, sexual violence can be accompanied by non-genital lesions, which was described in $10 \%$ of the reports analyzed in this study. Such findings demonstrate another of the consequences of sexual abuse, in addition to the moral and psychological damage, and the risks inherent to situations. ${ }^{7}$ The presence of non-genital lesions may help to characterize the use of physical force and coercion in sexual crimes, especially for victims over 14 years of age, when the consensual relationship does not constitute a crime. ${ }^{3}$

\section{Conclusion}

This work has the intention to help fill a gap resulting from the lack of research on sexual violence in Brazil. Its limitations are related to being a retrospective study, with data collected indirectly and not from the victim him/ herself. This prevented relevant data, that could be linked to the phenomenon of violence, such as the socioeconomic conditions of the victim and the perpetrator, is to be left out of the records. Additionally, the reports were incomplete, and because of this, the conclusion of the forensic examination was often deducted by the researchers based on the medical descriptions.

Similarly to what has been described by several authors, the main victims of sexual violence in this study were female children and adolescents with some form of emotional or parental relationship with the offender, which increases their vulnerability.

Sexual abuse against children and adolescents is a reality in Brazil and in the state of Paraíba, constituting a public health problem that deserves to be studied consistently, so that different players can contribute to the prevention and coping strategies of this problem.

The authors take responsibility for the entire content of the article. They point out author Luciana C. Trindade as responsible for the research, and declare no conflict of interest, stating that the work was approved definitively by the Research Ethics Committee of the FAMENE on 06.06.2012.

\section{SUMmary}

Violência sexual infantil e vulnerabilidade.

Objetivo: analisar o perfil demográfico e epidemiológico das crianças e dos adolescents vítimas de violência sexual atendidos em uma Unidade de Medicina Legal e o vínculo entre as vítimas e os autores.

Métodos: estudo descritivo, com coleta de dados a partir das informações dos laudos sexológicos, realizados no 
ano de 2009, das vítimas de violência com menos de 18 anos de idade. O instrumento de coleta foi um formulário com informações sociodemográficas sobre a vítima sexo, idade - e informações a respeito da violência sexual - local da ocorrência, tempo decorrido entre a violência e a perícia, queixas relatadas, achados do exame sexológico, descrição de lesões fora da região genital e vínculo entre a vítima e o agressor.

Resultados: no ano de 2009, foram atendidas 421 pessoas vítimas de violência sexual. Destas, 379 (90\%) eram menores de 18 anos, tendo sido excluídos 66 indivíduos desses laudos. A maioria era do sexo feminino (81,2\%). A faixa etária mais acometida foi a de 10 a 13 anos (36,7\%), seguida por 5 aos 9 anos (30,7\%). Na maioria dos casos $(86,3 \%)$, havia vínculo familiar ou de amizade entre as vítimas e os acusados, sendo o mais frequente o acusado conhecido ou amigo da família (42,3\%), seguido do padrasto $(16,6 \%)$ e do pai $(10,9 \%)$.

Conclusão: os resultados encontrados são semelhantes aos de outros estudos desenvolvidos no país. Este trabalho pretende preencher uma lacuna decorrente da escassez de pesquisas sobre esse tema no Estado, esperando colaborar nas políticas públicas de enfrentamento desse mal. Unitermos: Violência sexual; defesa da criança e do adolescente; vítimas de crime.

\section{REFERÊNCIAS}

1. Gawryszewski VP, Valencich DMO, Carnevalle CV, Marcopito LF. Maustratos contra a criança e o adolescente no Estado de São Paulo, 2009. Rev Assoc Med Bras 2012; 58(6):659-65.

2. Habigzang LF, Caminha RM. Abuso sexual contra crianças e adolescentes: Conceituação e intervenção clínica. São Paulo: Casa do Psicólogo, 2004.

3. Ribeiro MA, Reis JN, Ferriani MGC. Violência sexual contra crianças e adolescentes: características relativas à vitimização nas relações familiares. Cad Saúde Pública 2004; 20(2):456-64.

4. Teixeira SAM, Taquette SR. Violência e atividade sexual desprotegida em adolescentes menores de 15 anos. Rev Assoc Med Bras 2010; 56(4):440-6.

5. Zambon MP, Jacintho ACA, Medeiros MM, Guglielminetti R, Marmo DB. Violência doméstica contra crianças e adolescentes: um desafio. Rev Assoc Med Bras 2012; 58(4):465-71.

6. Polanczy GV, Zavaschi ML, Benetti S, Zenker R, Gammerman P, Wainber P. Violência sexual e sua prevalência em adolescentes de Porto Alegre, Brasil. Rev Saúde Pública 2003; 37(1):8-14.

7. Reis JN, Martin CCS, Ferriani MGC. Mulheres vítimas de violência sexual: meios coercitivos e produção de lesões não genitais. Cad Saúde Pública 2004; 20(2):465-73.
8. Pires ALD, Miyazaki MCOS. Maus-tratos contra crianças e adolescentes: Revisão da literatura para profissionais da saúde. Arq Ciência Saúde 2005; $12(1): 42-9$

9. Viodres Inoue SR, Ristum M. Violência sexual: Caracterização e análise de casos revelados na escola. Estud Psicol (Campinas) 2008; 25(1):11-21.

10. Gonçalves HS, Ferreira AL. A notificação da violência intrafamiliar contra crianças e adolescentes por profissionais da saúde. Cad Saúde Pública 2002;1 $8(1): 315-9$

11. Habigzang LF, Azevedo GA, Machado PX. Abuso sexual infantil e dinâmica familiar: Aspectos observados em processos jurídicos. Psic Teor Pesq 2005; 21(3):341-8.

12. Gomes R, Junqueira MFPS, Silva CO, Junger WL. A abordagem dos maustratos contra a criança e o adolescente em uma unidade pública de saúde. Ciênc Saúde Coletiva 2002; 7(2):275-83.

13. Azevedo MA, Guerra VNA. Crianças vitimizadas: A síndrome do pequeno poder. São Paulo: Iglu, 1989.

14. Barros FD. Vulnerabilidade nos novos delitos sexuais. Carta Forense. 2 março 2010. [citado 10 maio 2012]. Disponível em: http://www.cartaforense. com.br/Materia.aspx?id=5314.

15. Brasil. Lei 12015. 7 de agosto de 2009. Brasília (DF). [citado 10 maio 2012]. Disponível em http://www.planalto.gov.br/ccivil_03/_Ato2007-2010/2009/ Lei/L12015.htm\#art3.

16. Runyon MK, Kenny MC. Relationship of attributional style, depression and posttrauma distress among children who suffered physical or sexual abuse. Child Maltreat 2002; 7(3):254-64

17. Elliott AN, Carnes CN. Reactions of nonoffending parents to the sexual abuse of their child: A review of the literature. Child Maltreat 2001; 6(4):314 31.

18. Saywitz KJ, Mannarino A, Berliner L, Cohen JA. Treatment for sexually abused children and adolescents. Am Psychol 2000; 55(9):1040-9.

19. Cohen JA, Mannarino AP. Predictors of treatment outcome in sexually abused children. Child Abuse Negl 2000; 24(7):983-94.

20. Osofsky JD. The effects of exposure to violence on young children. Am Psychol 1995; 50(9):782-8.

21. Kellogg ND, Menard SW. Violence among family members of children and adolescents evaluated for sexual abuse. Child Abuse Negl 2003; 27(10):1367- 76.

22. De Antoni C, Koller SH. Violência doméstica e comunitária. In: Contini MLJ, Koller SH, Barros MNS (eds.). Adolescência e psicologia: Concepções, práticas e reflexões críticas. Brasília (DF): Conselho Federal de Psicologia, 2002. p.85-91.

23. Abdalla-Filho E. Quando o médico é o vulnerável. Bioética 2004; 12(2): 121-6.

24. Almeida LD. Suscetibilidade: Novo sentido para a vulnerabilidade. Bioética 2010; 18(3):537-48.

25. Meneghel SN, Barbiani R, Steffen H, Wunder AP, Roza MD, Rotermund J et al. Impacto de grupos de mulheres em situação de vulnerabilidade de gênero. Cad Saúde Pública 2003; 19(4):955-63.

26. Braz M. Bioética e violência. Bioética 2004; 12(2):77-98.

27. Sánchez AIM, Bertolozzi MR. Pode o conceito de vulnerabilidade apoiar a construção do conhecimento em Saúde Coletiva? Ciênc Saúde Coletiva 2007; 12(2):319-24.

28. De Lorenzi DRS, Pontalti L, Flech RM. Maus tratos na infância e adolescência: Análise de 100 casos. Rev Cient AMECS 2001; 10(1):47-52.

29. Morales AE, Schramm FR. A moralidade do abuso sexual intrafamiliar em menores. Ciênc Saúde Coletiva 2002; 7(2):265-73.

30. Lopes IMRS, Gomes KRO, Silva BB, Deus MCB, Galvão ERCGN, Borba DC. Caracterização da violência sexual em mulheres atendidas no Projeto MariaMaria em Teresina-PI. Rev Bras Ginecol Obstet 2004; 26(2):111-6.

31. Furniss T. Abuso sexual da criança: Uma abordagem multidisciplinar. Porto Alegre: Artes Médicas, 1993. 